\title{
Do consumers care about CSR in their online reviews?
}

\section{An empirical analysis}

David D'Acunto $^{\mathrm{a}, 1}$, Annamaria Tuan ${ }^{\mathrm{b}}$, Daniele Dalli ${ }^{\mathrm{a}}$, Giampaolo Viglia ${ }^{\mathrm{c}}$, Fevzi Okumus $^{\mathrm{d}}$

Keywords: corporate social responsibility; consumer online reviews; hotel industry; automated text analysis; environment

${ }^{\text {a }}$ University of Pisa, Department of Economics and Management, Via Ridolfi 10, 56124 Pisa, Italy.

${ }^{\mathrm{b}}$ University of Bologna, Department of Management, Via Capo di Lucca 34, 40126 Bologna, Italy.

${ }^{c}$ University of Portsmouth, Department of Marketing and Sales, Portland Street, PO13DE, UK.

${ }^{\mathrm{d}}$ UCF Rosen College of Hospitality Management, 9907 Universal Blvd. Orlando, Florida 32819 , US

${ }^{1}$ corresponding author (Email: david.dacunto@ec.unipi.it; phone number +39 3478575784 ) 


\title{
DO CONSUMERS CARE ABOUT CSR IN THEIR ONLINE REVIEWS? AN EMPIRICAL ANALYSIS
}

\begin{abstract}
This research investigates how consumers assess hotels' corporate social responsibility (CSR) practices when writing online reviews. The study explores the CSR discourse in online reviews over a 10-year period, highlighting how CSR's social and environmental dimensions relate to the main hospitality topics (experience, amenities, location, transactions, value). Based on a longitudinal automated text analysis covering 480,000 reviews across six European cities, the findings reveal that hotel customers have, with social and environmental factors trending in online review scores, gradually begun paying more attention to CSR dimensions. However, the aggregate results suggest that the overall CSR consumer discourse is still very limited, although it does have important implications in terms of consumer emotions and hospitality dimensions.
\end{abstract}

Keywords: corporate social responsibility; consumer online reviews; hotel industry; automated text analysis; environment

Article classification: Empirical paper

\section{INTRODUCTION}

The hospitality and tourism realm has seen a proliferation of review platforms where consumers can connect with one another effectively, share their consumption opinions ( $\mathrm{Li}$ et al., 2017), and find information about accommodation, restaurants, destinations, and other related products and services (Filieri \& McLeay, 2014). One of the best-known review 
platforms is TripAdvisor (www.tripadvisor.com), which has grown from 200 million online reviews in 2014 to more than 600 million posted reviews in 2017 and 100 million registered members (TripAdvisor, 2017). In short, online reviews have become key marketing levers for hospitality and tourism businesses (Leung et al., 2013, Levy et al., 2013). Their effective management affects room occupancy (De Pelsmacker et al., 2018), online booking transactions' average value (Torres et al., 2015), and consumers' willingness to pay positively (Nieto-Garcia et al., 2017). Consequently, online reviews currently play an even more critical role than before in terms of selling services and products (Schuckert et al., 2015).

Online reviews have therefore attracted more attention from marketing, e-commerce, and e-tourism scholars. Researchers in the hospitality and tourism field have mainly focused on how online reviews, considered an electronic version of traditional word-of-mouth (eWOM) (Filieri \& McLeay, 2014), affect travelers' information adoption practices and decision-making processes (e.g. Liu \& Park, 2015; Vermeulen \& Seegers, 2009; Ye, Law, \& $\mathrm{Gu}, 2009$ ). Online reviews are widely used as a tool for consumers to interact with peers, companies, and third parties. However, only a few studies have considered these reviews as data for corporate social responsibility (CSR) communication research (e.g. Brazytė et al., 2017; Ettinger et al., 2018; Lee et al., 2016; Yu et al., 2017) aimed at understanding whether and how consumers (tourists) explicitly or implicitly recognize CSR elements in their service experiences and at providing feedback about them (Ettinger et al., 2018). This is unfortunate, because consumers are increasingly paying more attention to CSR (Martínez \& Del Bosque, 2013; Holcomb et al., 2007; Pomering \& Dolnicar, 2009).

The importance of CSR has indeed grown over the last decade in several industries, including hospitality. On the one hand, hoteliers currently consider it important to pay attention to their social and environmental impact and to implement broad ranging social responsibility strategies (Brazytė et al., 2017; Randle et al. 2019). Global tourism's annual 
CO2 emissions increased by $15 \%$ in the $2009-2013$ period (Lenzen et al., 2018) with the accommodation sector itself contributing for $20 \%$ overall (Merli et al., 2019). On the other hand, tourism and hospitality consumers are also becoming more aware of CSR (Ayuso, 2006; Han et al. 2018), increasingly pushing hoteliers to report their responsible behaviors (Dodds \& Kuehnel, 2010). Given the hospitality industry's growing interest in CSR and firms' strong commitment to it (Kang et al., 2010), measuring consumers' level of CSR awareness is particularly relevant for the hospitality industry (Farrington et al., 2017; Kim et al., 2017), as it has been demonstrated that it can affect customers' satisfaction and purchase intentions positively (Kim, 2017; Randle et al. 2019; Su et al. 2015).

Online reviews are sources that can be used to evaluate consumers' level of CSR awareness. Consumers can use such reviews to not only evaluate others' accommodation experience, but also to express their opinions about a hotel's attention to environmental and social issues.

This research aims to investigate how consumers assess hotels' CSR when writing an online review about their accommodation experience. We have analyzed more than 480,000 TripAdvisor hotel reviews, covering 10 years (2006-2016) and the six most popular European tourist destinations (GDCI, 2015) by means of automated text analysis. Building on e-WOM and CSR research streams, this study contributes to the hospitality and tourism domains by providing new evidence about consumers' CSR-related online discourses (DiPietro et al., 2013; Ettinger et al., 2018; Liu et al., 2014; Xu, 2014). Our findings suggest that, even though consumers are paying more attention to social issues rather than environmental ones, online reviews with environmental topics are associated with positive emotions and higher rankings. Conversely, online reviews focusing on social issues are associated with negative emotions and lower rankings. Moreover, it is possible that consumers tend to evaluate their overall experience and their location by focusing more on environmental topics than on social ones. 
This study's contribution is fourfold: we extend prior findings about consumers' perception of CSR in their online reviews by analyzing a robust dataset covering six major European cities over a 10-year period; by combining three dictionaries to perform automated text analysis, we not only analyze online reviews' content, but also their sentiment (positive and negative emotions), thus obtaining details beyond the mere review rankings; we contribute to the CSR literature from a consumer perspective, which is scarce compared to the more general company-oriented CSR literature; and we emphasize that not all CSR elements carry the same weight by contributing to the ongoing discussion. From a managerial perspective, these results give hotel managers opportunities to understand their guests' attention to social and environmental issues and to related areas of improvement.

\section{LITERATURE REVIEW}

\subsection{E-WOM in hospitality: Online reviews as a tool to describe a hotel experience}

The internet and user-generated content (UGC) have revolutionized the way consumers search for information (Buhalis \& Law, 2008; Bronner \& De Hoog, 2011), enabling travelers to interact and collaborate (Sigala, Christou, \& Gretzel, 2012) and increasing the electronic word-of-mouth (e-WOM) phenomenon (Litvin et al., 2008). Of all UGC, online reviews, considered electronic versions of traditional word-of-mouth actions (Filieri \& McLeay, 2014), are one of consumers' most popular tools (Chatterjee, 2001) for evaluating their experiences and connecting directly with companies.

When communicating about a company's products and services, customers become "objective voices" (Vermeulen \& Seegers, 2009), with more than $75 \%$ of consumers taking peer reviews into account when planning a holiday (Xie et al., 2014), which therefore inform their decision-making processes (Cantallops \& Salvi, 2014; Mackay \& Vogt, 2012). According to Kim et al. (2011), three main motivations encourage consumers to read online 
reviews while searching for accommodation: i) the convenience and quality, ii) risk reduction, and iii) social reassurance. Consumers mainly write reviews to inform peers about their accommodation experience (Park \& Allen, 2013) and to share their level of satisfaction (Liu et al., 2014). Since the quality of hotel services is often unknown before the consumption experience, consumers tend to rely more on peers' feedback (Filieri et al., 2015; Park, Lee, \& Han, 2007; Wirtz \& Chew, 2002) than on corporate sources.

Consumer reviews' main features are the rating (e.g. stars) and content. While ratings represent an important cue and are a proxy of the overall satisfaction level (Zhou et al., 2014), a review's content offers more detailed data that influences future customer demand and hotels' financial performance (Xie et al., 2014). In particular, online review text is important because it includes affective words conveying positive and negative emotions and strengthening a review's intent. Emotions are more important than customer satisfaction when customers provide WOM (Sukhu et al, 2019), especially as online reviews' emotional tone has been identified as a driver that affects the readers' purchase intentions and reviews' conversion rates (Ludwig et al., 2013).

Content and narrative analyses of consumer reviews have attracted considerable attention in recent studies, because they provide insight into consumption experiences (e.g. Van Laer et al., 2018; Villarroel Ordenes et al., 2018). Such analyses could highlight service features that consumers find more important and provide more detailed interpretations of their perceptions (e.g. Xiang et al., 2015; Berezina et al., 2016; Xu \& Li, 2016; Zhao et al., 2019). Based on the main topics discussed in online reviews, Zhou et al. (2014) identified the key attributes that affect customer satisfaction: i) the room facilities, ii) general hotel facilities, iii) food quality and dining environment, iv) price, v) location, and vi) service and staff. Gao and Mattila (2014) found that, in the accommodation realm, the servicescape's social and physical dimensions drive customer satisfaction (Zeithaml et al., 2006), while green practices tend to 
reflect people's emotional needs (Kang et al., 2012; Sen \& Bhattacharya, 2001) rather than their functional ones. On the other hand, by using a topic discovery learning model, Mankad et al. (2016) found that hotel reviews mainly consist of five topics pertaining to the i) hotel amenities, ii) hotel location, iii) the transactional mechanics of the stay, iv) perceived value for money, and v) the overall experience.

As mentioned earlier, a specific focus on whether and how online review content is related to CSR dimensions is still lacking, as these reviews are becoming more important in the hospitality literature.

\subsection{Corporate social responsibility in the hospitality literature}

Over the past three decades, CSR has emerged as an important construct in several academic disciplines, such as environmental studies, marketing, organizational theory, strategy (Aguinis \& Glavas, 2012), and business practice. Recent evidence suggests that between 2014 and 2017, sustainability's share in terms of sales grew nearly three percentage points, while conventional products' share dropped by almost four (Nielsen, 2018). Millennials are also more likely than Baby Boomers (53\% vs. $34 \%$ ) to buy products that are environmentally friendly.

By CSR we mean "context-specific organizational actions and policies that take into account stakeholders' expectations and the triple bottom line of economic, social, and environmental performance" (Aguinis, 2011, p. 855). The economic, social, and environmental spheres are the main three areas in which CSR actions are usually implemented.

The economic dimension is crucial, because a company has to be profitable in order to execute other types of responsibilities and to manage its impact on society and on the environment (Carroll et al., 2010; Weber, 2008). The social dimension covers an organization's responsibility for social issues and related activities in terms of its internal (e.g. 
employees) and external (e.g. consumers, suppliers, or NGOs) stakeholders, as well as all actions focused on the community in which a company operates (Porter \& Kramer, 2006). In their conceptualization of CSR's social dimension, scholars (Giuliani et al., 2016; SchrempfStirling \& Wettstein, 2017) have recently started paying attention to the role of human rights - the inalienable fundamental rights to which a person is inherently entitled simply by virtue of being a human being (World Conference on Human Rights, 1993). The environmental dimension deals with the organization's responsibility towards environmental and natural resources, as well as with related topics, like water, energy, certifications, waste, pollution, bio-diversity, natural gas, the greenhouse effect, and material stewardship (e.g. Babiak \& Trendafilova, 2011; Welford et al., 2008).

CSR actions can take many forms - such as waste management programs, diversity initiatives, employee or community engagement activities, green material usage, and monetary donations to charities (Sen \& Bhattacharya, 2001) - which are increasingly being implemented in the hospitality industry.

In line with general management studies, the focus on CSR has grown in the hospitality and tourism literature (e.g. Farrington et al., 2017; Holcomb et al., 2007). Although Goldstein and Primlani (2012) traced the origins of hotel sustainability back to the 1960s, mainly as a form of companies' voluntary and philanthropic acts, the leading global chains only started implementing environmentally friendly practices and numerous CSR initiatives to serve their local communities and improve their employees' well-being from about 2000 (Butler, 2008; Chan, 2013). For instance, AccorHotels has made a commitment the Planet 21 program - to accelerate and intensify the group's sustainable development in terms of introducing eco-friendly products and reducing its energy and water usage (Planet 21 Accor Hotels, 2018). Best Western Hotels \& Resorts joined the project "Stay for the Planet," 
carrying out energy-efficient actions and reducing its environmental impact (Best Western, 2018).

Several scholars have investigated CSR in the hotel industry from different points of view, revealing, for instance, how CSR actions affect hotel outcomes in terms of financial performance and consumer loyalty (Liu et al., 2014), how they create a positive social impact in the external community (Nicolau, 2008), and how hotel chains communicate about CSR on their websites (Holcomb et al., 2007; Jones et al., 2016). Moisescu (2015) suggested that CSR communication can be very effective, but it can also be a "double edged sword" (Sen et al., 2006) by enhancing skepticism and the perception of greenwashing. Hotels therefore face the challenge of promoting an environmentally friendly image while avoiding accusations of greenwashing (Chan, 2013; Helen Chun \& Giebelhausen, 2012). Despite a large number of studies focusing on the range of CSR practices that hotels implemented and communicated (e.g. Bohdanowicz, 2006; Bohdanowicz et al., 2011; Erdogan \& Baris, 2007; Sparks et al., 2013), there is as yet little analysis of consumers' perception of CSR actions in the hotel industry (Ettinger et al., 2018).

\subsection{Do hotel guests care about corporate social responsibility?}

Consumers are the most influential group regarding exerting pressure on hoteliers to adopt greener practices and codes of ethics (Ayuso, 2006). This is consistent with other industries in which companies adopt CSR practices to respond to external pressures and in a bid to gain legitimacy and enhance their reputation (e.g. Bhattacharya \& Sen, 2003; Du et al., 2007). In the same vein, online reviews play a major role in CSR communication (Ettinger et al., 2018; Öberseder et al., 2011). By providing a review online, consumers can, as mentioned previously, express their level of satisfaction or dissatisfaction with their accommodation experience, as well as the social and physical servicescape (e.g. the interior facilities, the 
building, and interaction with the employees), but also express how they perceive and evaluate hotels' CSR practices, thus creating a dialogue with them.

To the best of our knowledge, research on this topic has been scant and fragmented. Previous research suggests that pro-environmental behavior is more common in daily activities than while traveling (Dolnicar \& Grün, 2009; Miao \& Wei, 2013). When consumers write an online review, do they evaluate their accommodation experience in terms of corporate social responsibility? Ettinger et al. (2018) have, for instance, documented how guests comment on hotels' CSR engagement by analyzing a small sample of Austrian hotels and showing that environmental issues and supplier relations are most commented on in customer reviews. By analyzing hotel guests' willingness to report on green content in their online reviews and, in turn, the management response rates, Lee et al. (2016) investigated these guests' perception of green practices. Yu et al. (2017) analyzed online reviews to understand the relationship between green practices and customer satisfaction, although the authors' study only concentrated on a sample of 10 green hotels in the USA. Peiró-Signes et al. (2014) analyzed the impact of hotels with an ISO 14001 environmental certificate on customers' perspective, finding that guests rate hotels with an ISO 14001 certificate higher than those without it. Furthermore, Brazytė et al. (2017) focused on a small sample of Costa Rican hotels with a sustainability certificate to explore how guests respond to sustainability efforts in their online reviews. These authors found that customers who explicitly recognize a hotel's implemented sustainability measures tend to provide higher ratings in their reviews.

Despite the topic's growing importance, it is clear that the few contributions in the field only focused on small samples in specific contexts (e.g. the USA, Austria, and Costa Rica), or only on green hotels, where consumers who are already keen on sustainable practices will stay, thus potentially biasing the results. 
Building on previous work, this study aims to contribute to this research stream by providing insights into consumers' overall attention to CSR in the hotel industry. We used a novel dataset comprising more than 480,000 reviews over a period of 10 years of hotels in the six most important tourist destinations in Europe, according to GDCI (2015). The study aims to answer the following research questions:

RQ1: Has the attention consumers pay to CSR-related factors in the hotel industry evolved over time?

RQ2: To what extent do consumers explicitly recognize and report CSR-related elements in their online reviews of their accommodation experience?

$\boldsymbol{R Q 3 a}$ : To what extent are the CSR dimensions discussed in online reviews associated with emotional content?

$\boldsymbol{R Q 3 b}$ : To what extent are the CSR dimensions discussed in online reviews associated with ratings?

$R Q 3 c$ : To what extent are the CSR dimensions discussed in online reviews associated with hospitality topics?

\section{METHODOLOGY}

\subsection{Method}

Textual user-generated web content provides an extensive shared cognitive and cultural context (Xiang et al., 2017). We adopted a longitudinal design and analyzed the data through automated text analysis to identify and describe consumer feedback patterns over time. In particular, we employed consumer-generated online reviews to see whether and how consumers talk about CSR-related elements when they evaluate their accommodation experiences. We used Linguistic Inquiry Word Count (LIWC) (Pennebaker et al., 2007), a software package used by various scholars in different academic fields, ranging from 
psychology (e.g. Boyd \& Pennebaker, 2017) to marketing (e.g. Hewett et al., 2016) and consumer behavior (e.g. Humphreys \& Wang, 2017), to analyze consumers' reviews. In the tourism and hospitality literature, LIWC has been applied to run sentiment analyses of online reviews (Liu et al., 2019; Ma et al., 2018) and to explore the linguistic style and semantic relevance of management responses (Li et al., 2017).

This software allowed us to process text (e.g. an online review) and count the number of times a specific word appears compared to the total number of words in that text. Words were listed in predefined repertoires, usually defined dictionaries, in which they were classified into categories of meaning (e.g. emotions, thinking styles, and social concerns). We used three dictionaries, already tested in extant hospitality, management, and marketing literature, to run the automated content analysis:

1. CSR dictionary: To identify the CSR dimensions and detect the ones consumers considered most frequently, we used the CSR dictionary developed by Pencle and Mălăescu (2016), which focuses on social and environmental CSR categories. We merged the categories "human resources," "human rights," and "social \& community" into a broader social category by following the CSR definitions provided in previous literature (Aguinis \& Glavas, 2012). Thereafter, we categorized the review texts according to two dimensions: social and environmental.

With the social CSR dimension we refer to social activities related to philanthropy, community projects, charities, employees' relations, and their welfare, while the environmental CSR dimension refers to eco-friendly activities related to waste reduction, energy conservation, and environmental protection.

It is worth noting that we do not aim to assess the CSR practices that hotels implement. The CSR dictionary helps provide an overview of consumers' descriptions 
of the social as well as environmental CSR dimensions in their online reviews, thus providing insights into the attention they pay to CSR.

2. Positive/negative emotions: We used the LIWC to assess the level of affective content in terms of positive and negative emotions. These categories appear in the marketing and management literature (e.g. Hewett et al., 2016; Ludwig et al., 2013).

3. Hospitality topics: We relied on the Mankad et al. (2016) classification of the hospitality topics discussed in online reviews. This dictionary provides detailed semantic areas for different hospitality topics in online reviews, namely the amenities, location, transactions, value, and experience.

Table 1 summarizes the structure of the dictionaries used for the analysis:

Table 1. Dictionaries used in the analysis

\begin{tabular}{|c|c|c|}
\hline Category & $N^{\circ}$ of words & Examples \\
\hline CSR-Social & 623 & $\begin{array}{l}\text { Healthcare, employees, equal opportunities, } \\
\text { respect, charity, local development, } \\
\text { philanthropic, social policy }\end{array}$ \\
\hline CSR - Environmental & 451 & $\begin{array}{l}\text { Clean energy, waste reduction, air filtration, } \\
\text { carbon emission, sustainable, green building, } \\
\text { eco-system, water purification }\end{array}$ \\
\hline LIWC-Positive emotions & 620 & Love, nice, sweet \\
\hline LIWC-Negative emotions & 744 & Hurt, ugly, nasty \\
\hline Hospitality 1: Amenities & 30 & Breakfast, bar, food, bed, comfort, wifi \\
\hline Hospitality 2: Location & 30 & Center, walk, location, station, shop, restaurant \\
\hline Hospitality 3: Transactions & 30 & Check, booking, reception, front, desk, service \\
\hline Hospitality 4: Value & 30 & Price, better, business, star, standard, need \\
\hline Hospitality 5: Experience & 30 & Great, excel, recommend, perfect, view, love \\
\hline *stemmed words & & \\
\hline
\end{tabular}

\subsection{Data}

The database consisted of hotel guests' reviews of a popularity index's (GDCI, 2015) list of the six top European destinations, namely Amsterdam, Barcelona, Istanbul, London, Paris, and Rome. This index ranks the top travel destinations worldwide based on the overnight incoming visitor volume and expenditure. We decided to focus on Europe, as it is the main 
tourist destination area worldwide (UNWTO, 2018), thereafter selecting popular destinations in different countries to ensure a certain degree of variety in the sample. Using a web crawler, we retrieved the total number of hotel reviews from TripAdvisor, the most frequently used data source in the hospitality context (Ma et al., 2018; Mkono \& Tribe, 2017). We collected more than two million consumer reviews written in English from 2006 to 2016 concerning the selected cities. For the purpose of this study, we excluded reviews with incomplete information. The final sample yielded 487,100 reviews (Table 2).

Table 2. Descriptive statistics of the sample

\begin{tabular}{l|cc}
\hline City & $\boldsymbol{n}^{\circ}$ of reviews & \% \\
\hline London & 184,584 & $37.9 \%$ \\
Paris & 88,048 & $18.1 \%$ \\
Rome & 63,492 & $13.0 \%$ \\
Barcelona & 57,205 & $11.7 \%$ \\
Amsterdam & 53,316 & $10.9 \%$ \\
Istanbul & 40,455 & $8.3 \%$ \\
\hline Total & $\mathbf{4 8 7 , 1 0 0}$ & $\mathbf{1 0 0 \%}$
\end{tabular}

For this study, we selected all the reviews listed on TripAdvisor as originally written in English, since translations from other languages may lead to data loss or misinterpretation and to allow us to apply the dictionaries, which were developed for texts in English.

\section{FINDINGS}

\subsection{The evolution of the CSR discourse in online hotel reviews}

To answer the first research question, we used automated text analysis to measure whether and how consumers evaluate CSR elements in their online reviews over time. By using the LIWC, each review received a score for the environmental category and one for the social category. These scores represented the percentage of words related to these categories in the 
relevant reviews compared to the total word count. Figure 1 shows the aggregate level of the main CSR dimensions' evolution in consumers' online reviews.

Figure 1. The trend in CSR dimensions over time

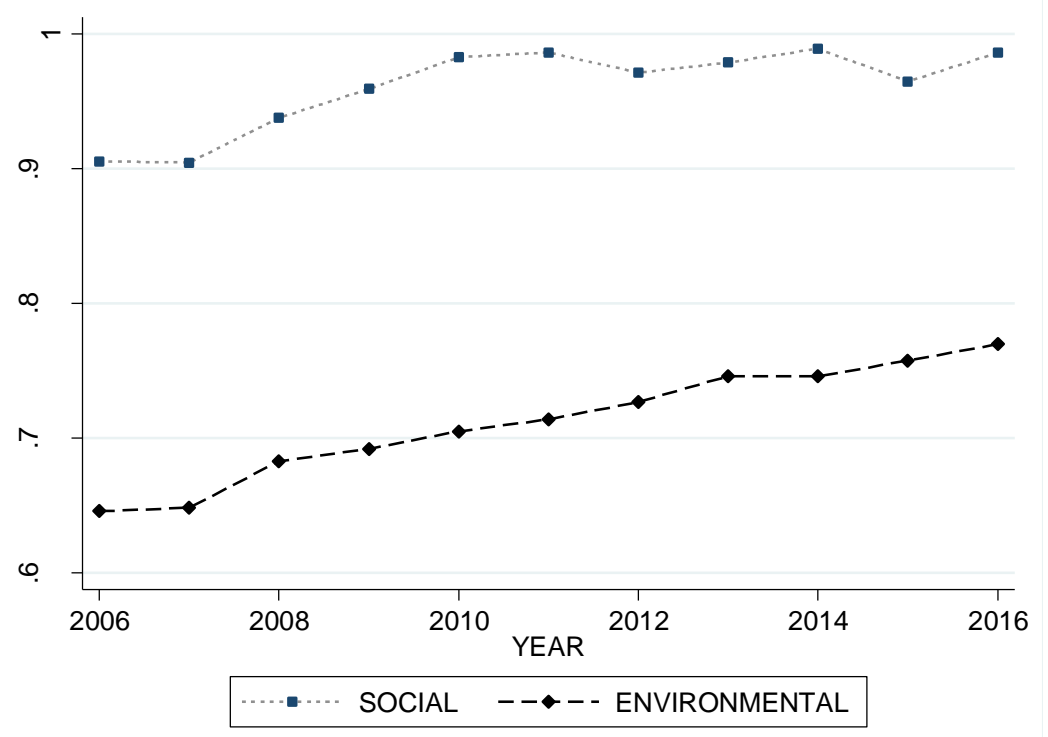

These findings show that although consumers' attention to CSR dimensions started at a low level, it has increased since 2006. Interestingly, customers seem to be more involved in the social aspects of CSR than in the environmental ones. By running an ANOVA test, we compared the cities in our dataset and found significantly different levels of CSR elements in the online reviews' content $\left(F_{\text {SOCIAL }}(5)=205.60, p<0.05 F_{\text {ENVIRONMENT }}(5)=841.00, p<0.05\right)$. After a post hoc analysis, with the exception of Amsterdam and Rome in respect of the social dimension, all the differences were statistically different.

London hotels revealed the highest scores in terms of the social dimension, followed by Istanbul, while Barcelona took the last place. Amsterdam hotels had the highest levels in terms of the environmental dimension, followed by Barcelona, while London and Paris had the lowest levels (Figure 2). This is consistent with Amsterdam being the greenest city of those considered (Boes et al., 2015; Dameri, 2014). These results indicate that the social dimension's general predominance over the environmental one is confirmed at the individual 
city level, even if the difference between the two dimensions is negligible in Amsterdam and Barcelona, while the difference is bigger in London, Paris, and Rome.

A possible explanation might be that hotel guests prefer to report their "social" experiences to highlight their relationship with hotel employees or when explaining the facilities available for disabled guests. These topics appear to have a more immediate impact in terms of actual guests' satisfaction when they report on their experiences. Although environmental issues are growing in importance, they do not have an immediate impact on the accommodation experience and might only be considered key in terms of green-oriented customers.

All in all, it is important to understand whether social and environmental topics are discussed in positive or negative terms in reviews. In the following section, we will delve deeper into this topic.

Figure 2. CSR dimensions relating to different cities

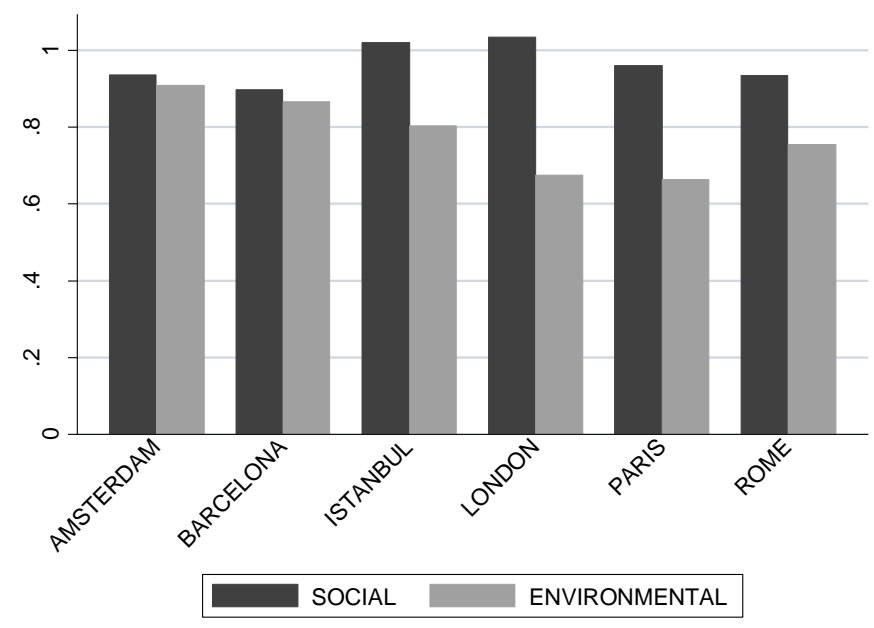

\subsection{The relationship between CSR dimensions and sentiment}

We subsequently analyzed the correlation level between the emotional tone of reviews' content and the two CSR dimensions by running automated text analyses with LIWC. The results show a significant, although moderate, positive correlation between the environmental 
dimension and positive emotions $(r=0.072, p<0.01)$, while there is a negative correlation regarding the negative emotions $(r=-0.045, p<0.01)$. Consequently, when customers review their experience and are focused on environmental elements, they tend to express positive emotions and do not mention the negative ones much. It seems that online reviewers appreciate the environmental dimension of their experience with a hotel. The social dimension presents a different pattern in that it is positively correlated with negative emotions $(r=0.108, p<0.01)$ and slightly positively correlated with positive ones $(r=0.007, p<0.01)$. The more reviewers write about the social dimension, the more they express negative emotions, with virtually negligible effects on positive ones. In this case, it seems that the reviewers were disappointed with issues related to the social dimension of their experience. These relationships are further confirmed when examining the ratings, a result suggesting that hotel managers should be aware of reviews with lower scores and lower rankings, because they might provide useful areas of improvement in the social dimension.

\subsection{The relationship between CSR dimensions and rating}

We measured the relationship between CSR dimensions and review scores with an ANOVA test and found that consumers' environmental and social attention in online reviews differ greatly in terms of their review scores $\left(F_{\text {SOCIAL }}(4)=1282.80, p<0.05 F_{\text {ENVIRONMENT }}(4)=\right.$ 542.81, $p<0.05)$. After a post hoc analysis, all the differences were statistically different, with the exception of levels 4 and 5 in the environmental dimension. Figure 3 shows that the environmental dimension was higher in reviews with higher review scores, indicating a positive relation between the two dimensions. On the other hand, the social dimension was lower in reviews with high scores, following a negative relation with the review score. This finding suggests that satisfied consumers evaluate the environmental elements positively when they review their experience. This is in line with previous research, which suggested 
that the environment, as part of the tourism product, affects tourists' satisfaction with their experience (Ettinger et al., 2018; Frey \& George, 2010; Rodríguez \& Cruz, 2007). At the same time, as evidenced by the analysis conducted in the former section, we found that satisfied consumers mentioned the social CSR elements less than dissatisfied ones. In general, social issues are more frequently mentioned in negative reviews, as environmental issues are more frequently mentioned in positive reviews. Consequently, corporate responsibility's social dimension satisfies tourists in our dataset less than the environmental dimension in their hotels. Hotel managers should therefore improve their efforts in terms of social responsibility and their related communication. Examples of suggested activities in the social domain of CSR are provided in the managerial implications section.

Figure 3. CSR dimensions vs. reviews' rating

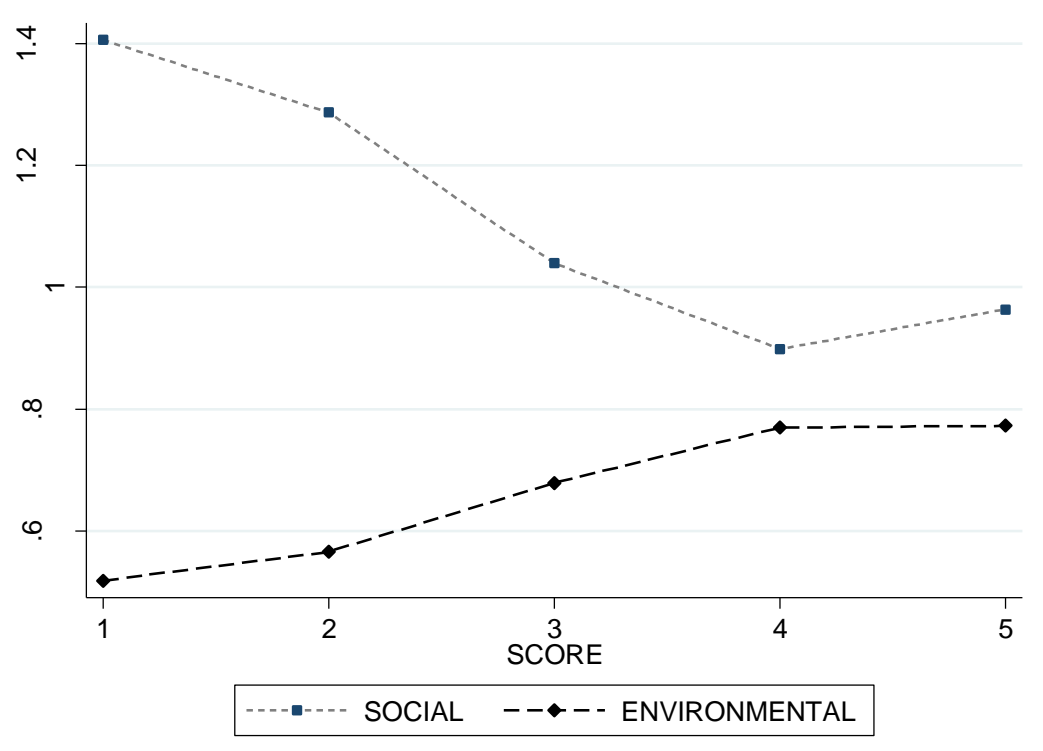

In order to delve deeper into this topic, we provide examples of online reviews with high scores and attention focused more on environmental issues. For instance, a woman reviewed her experience in a 5-star Amsterdam hotel in June 2017: 
"I'm guessing that you've never stayed in a hotel that wanted to have a personal relationship with you. [...] Outside on the street the hotel greets you and across from the front door a sign asks you to respect the protected area where bicycles congregate and breed. This will sound either cute and quirky or too twee for words, but it grows on you. The serious message of the Conscious Hotel is sustainability and general eco-friendliness. The breakfast food tends to be organic and one wall of the lobby is covered with ferns and moss. [...]" (original review in the appendix).

In July 2016, another customer released a detailed review about a hotel in Barcelona: "Another place that made my stay priceless was the eco-friendly hotel I spent my nights at: Hostal Grau. [...] Just for you to get an idea, the room I stayed at was called the "OFF Room" and it took sustainability to the next level! The minute I opened my room's door I was surprised with 1) an eco-mattress made from coconut fibre, recycled denim and other natural fibres (so comfy it left me in awe!) 2) sheets made from organic cotton 3) furniture made from recycled wood 4) Eco wifi, which reduces the radiation effect [...] As if that were not enough, every furniture piece in the hotel was recycled and visitors could rent bikes to drive around the city! Cutest eco-friendly boutique hotel in town!'” (original review in the appendix)

In these cases, the consumers evaluate their accommodation experience by mainly focusing their attention on environmental issues, such as organic breakfasts, dedicated areas for bikes, or furniture made from recycled materials, which improved their overall experience. Conversely, when consumers perceive a service failure in terms of the social elements during their stay, this is also reflected in the review's score, which is then negative. For example, a customer reviewed a 1-star hotel (London, August 2014), complaining about the poor facilities for disabled people: "Went to a wedding at the Cumberland with my disabled mum. Disabled access very poor-toilet for disabled nowhere near the hall and through 2 heavy doors! My son had an accident while there (not the hotel's fault) but waited 20 mins for a first 
aid kit which was incomplete and they had no first aider on duty. [...]" (original review in the appendix).

\subsection{The relationship between CSR dimensions and hospitality topics}

When examining the correlations between the social and environmental dimensions and the five key hospitality areas identified by Mankad et al. (2016), the main finding shows a positive correlation between the environmental dimension and the overall experience and location, but a negative one with transactional aspects (Table 3). The environmental dimension, experience, and location have a positive and linear correlation with ratings, while the transactional aspects have a negative and linear correlation.

Satisfied consumers therefore report on their hotel stay by writing about their overall experience and about the location by focusing on environmental issues. This is in line with results provided by Xiang et al. (2015), who found that guests' experience and the hotel location are highly associated with guest satisfaction and, in turn, with reviews' ratings.

Table 3. Correlation matrix between CSR dimensions and hospitality dimensions

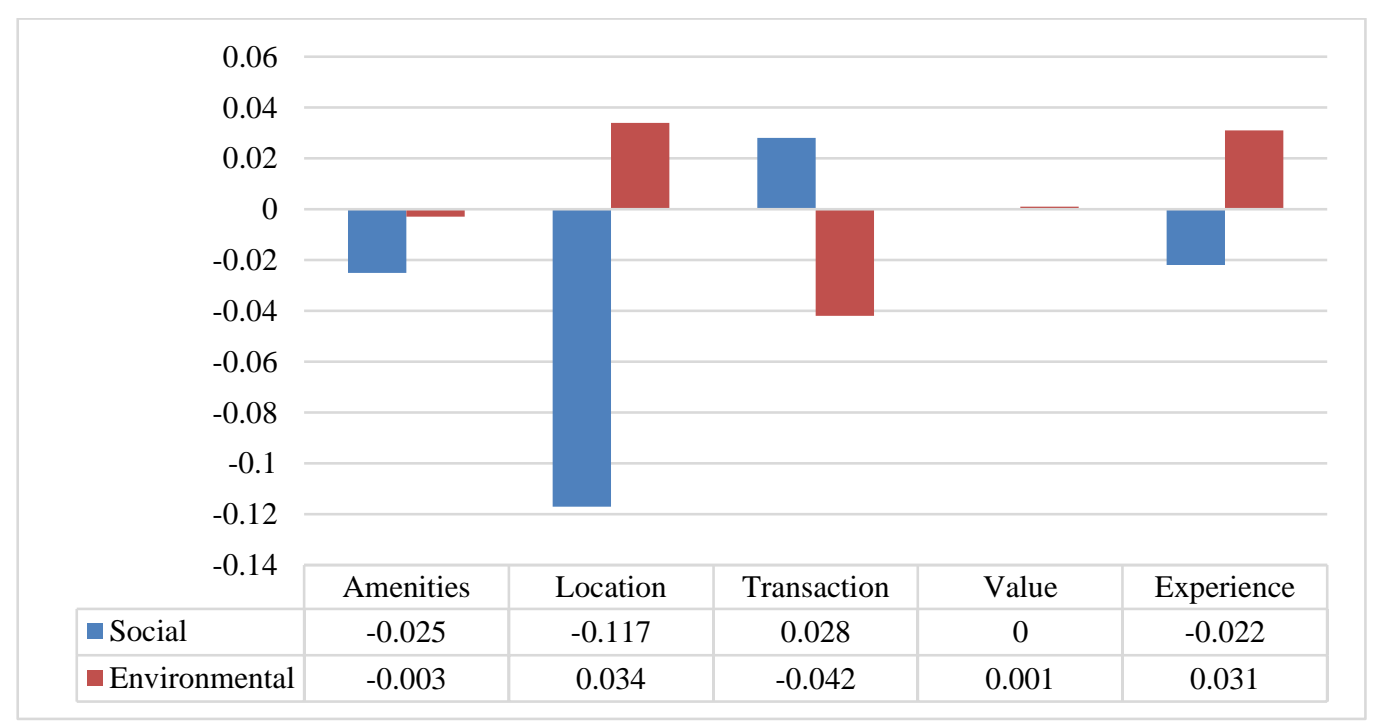

All correlations are significant, except those related to the value dimension 
The social dimension, on the other hand, is negatively correlated with the location and the experience, but positively with the transactional aspects for basically the same reasons, although in the opposite direction. The correlation with the location appears particularly intense and negative, as if people who focus on a hotel location's attractiveness do not report on the social issues, positive or negative. Likewise, people who report on the social issues do not focus on the location. The same applies to the hotel's amenities, although less so.

The category "experience" contains words related to positive topics and feelings like "love," "fun," and "enjoy." The positive/negative association between experience and either the environmental or social dimension confirms our previous findings regarding emotions and CSR dimensions, further validating our previous results. The result of the category "location" is interesting. It seems that consumers also appreciate hotels' location (e.g. the walking distance from the city center or whether it is close to a train station) from an environmental perspective, suggesting that hotel managers should emphasize these aspects in their communication strategies. For example, a customer reviewed a 4-star hotel (Amsterdam, July 2012) showing his excitement with the green hotel's location and the possibility of enjoying the city on foot or by public transport, and reducing pollution while saving money:

"[...] this is a conveniently located, green property that engages in ethical and environmentally friendly business practices ... tree trunks for bedside tables, a desk made out of recycled coffee cups, and energy saving shower [...]A great location[...]The Schiphol Airport public transportation bus stops right across the street. Take the red bus numbered 197 from the Airport and get off at the Concert Hall stop, when you get off the bus, cross the street and go right, the hotel is number 7. Could not be easier and only 4 Euros one way and fast too. $[\ldots]$ '. (Original review in the appendix).

\section{DISCUSSION AND CONCLUSIONS}


This study provides an overview of the CSR dimensions in consumers' online reviews between 2006 to 2016, showing how the attention paid to these dimensions in the hospitality industry has evolved (Figure 1). Despite governments, companies, and other stakeholders showing a keen interest in sustainability and CSR, hotel customers do not to respond with the same commitment when reviewing their stay. With a decade-long longitudinal sample covering more than 480,000 reviews across six European cities, we provide evidence that consumers' level of awareness of CSR activities is still scant, although it has grown significantly over this period.

Furthermore, this research highlights how CSR elements relate to reviews' sentiment and their rating. Interestingly, experiencing environmental elements during a stay leads to subsequently higher positive emotions and ratings in consumers' reviews. Conversely, the social dimension of CSR presents more controversial findings. Specifically, consumers who discuss these aspects more are associated with more negative ratings and emotions. When investigating how the different hotel attributes relate to CSR elements, we find that environmentally satisfied customers tend to focus on the location and their overall experience in their judgment. However, a focus on CSR's social dimension presents a rather different story, as consumers who mention this are keener to focus on transactional areas.

\subsection{Theoretical implications}

This study contributes to existing literature in four ways. First, we extend prior findings by focusing on consumers' perceptions of CSR in online reviews (e.g. Ettinger et al., 2018; Brazytė et al., 2017; Lee et al., 2016; Yu et al., 2017). By using a large sample of reviews from six major European cities and in a longitudinal timeframe, we provide a more detailed picture of CSR in the hotel industry from the consumer perspective. 
Second, we contribute to the more general CSR literature from the consumer point of view (e.g. Pomering and Dolnicar, 2009; Sen et al., 2006). Most of the literature focuses on the company point of view in order to assess the level of CSR implementation and communication. However, research on consumers' attention to CSR is still growing, which is mainly due to assessing consumers' actual evaluation of CSR not being an easy task. The literature has long established that there is gap between consumers' asserting that they are "green-oriented" and their actual consumption of green products (e.g. Auger et al., 2003; Auger \& Devinney, 2007; Devinney et al., 2010). Consequently, surveys of or interviews on consumers' attention to CSR activities can lead to biased results. Analyzing the raw data in online reviews can provide a far more truthful picture, as well as useful and actionable suggestions for managers. Our findings show that the online review content referring to CSR elements increased from $1.55 \%$ in 2006 to $1.76 \%$ in 2016 , meaning that consumers' level of attention to hotels' CSR activities has grown, but is still low. This finding is in line with previous findings by Lee et al. (2016), who, despite in a small sample, show that guests tend not to mention hotels' green practices in their reviews, even after staying at top green hotels.

Third, this research also contributes to the ongoing discussion suggesting that not all CSR elements carry the same weight (Ettinger et al., 2018). We provide evidence that the two main emerging CSR dimensions (social and environmental) are growing. We also present different trends over time and different patterns across six cities' cultural and geographical settings. As we have seen, consumers frequently use topics related to the social category in their reviews, which are associated with negative emotions and - more importantly - with lower ratings. The environmental elements, which are associated with positive emotions and higher ratings, are also growing in terms of citations in online reviews.

Fourth, we contribute to the extant literature by integrating three dictionaries used in the automated text analysis into the same study in order to not only assess the content of 
online reviews (CSR and hospitality), but also their sentiment (positive and negative emotions). Previous studies mainly analyzed how reviews' content was related to their ratings without delving deeper into the emotional style of online reviews.

\subsection{Managerial implications}

From a managerial standpoint, this research offers the following three actionable levers for managers: First, since consumers generally consider negative reviews more useful (Racherla \& Friske, 2012; Ahluwalia \& Shiv, 1997), hotel managers should carefully consider initiating and improving appropriate initiatives and related communication in corporate responsibility's social dimension (e.g. donating a proportion of the yearly income to local charities, using renewable indigenous materials, helping to educate local communities to be more self-sufficient, helping the long-term unemployed find work through custom-made training programs, helping refugees find permanent work).

Second, hotels should make their CSR commitment known. A possible activity could include customers' reviews with CSR content in corporate CSR communication strategies. This would enhance two-way interactive communication, which has been shown to be more effective than one-way communication, such as CSR industry reports or static communication on the corporate website (Morsing \& Schultz, 2006). As previously pointed out, consumers tend to rely more on peers' feedback, because they regard it as a more trustworthy source (e.g. Filieri et al., 2015). Specifically, when dealing with international hotel chains, consumers are often confused, because they cannot determine whether and to what extent the hotels have implemented CSR activities (De Grosbois, 2012). Consequently, frontline employees (such as receptionists and service staff) need to be properly trained to explain CSR programs and stimulate consumers to become involved in CSR initiatives (Wang et al., 2016). 
Third, hotels should begin engaging customers actively to co-create CSR value. Platform use experience is an important starting point in value co-creation (Zhang et al., 2018). Showing consumers that the savings from some of the implemented activities, such as towel recycling, are shared with them would be an effective way of attracting their attention. In this sense, Dolnicar et al. (2017) suggest that including tangible benefits for consumers will have positive implications in terms of e-WOM.

Finally, as previously suggested, it is worth noting that pro-environmental behavior is more common in daily activities than while traveling (Dolnicar \& Grün, 2009; Miao \& Wei, 2013). Consequently, new government policy incentives should raise awareness and drive a change in guests' behavior, (e.g. higher taxes for non-green hotels).

\subsection{Limitations and future research}

This study has several limitations. It was undertaken from a consumer perspective and we did not investigate whether and how hotels respond to reviews. It is worth noting that by considering their hotel choice as a funnel process, guests may not mention CSR in online reviews, but they might go to hotels they perceive as sustainable from the beginning. Customers may self-select sustainable hotels in line with their preferred decision mode, which Kim et al. (2019) recently suggested. Scholars do indeed assume that decision modes (choice vs. rejection mode) affect travelers' preferences for a sustainable option over a less sustainable one. Customers in the choice decision mode pay more attention to their option's positive features in order to justify their choice, whereas customers in rejection mode focus on their option's negative features to justify their rejection. As a consequence, a CSR-friendly brand image should help facilitate consumers' choice at the initial stage. A CSR accreditation that indicates the sustainable hotels on TripAdvisor would also help. Future studies should examine the funneling process by checking the way consumers select sustainable hotels based on their brand image and how they report their experiences in online reviews. Our approach 
aimed to provide a perspective on a topic that is still largely unexplored. A design that examines causal relationships, testing the impact of CSR awareness actions (activities developed by hotels) on the online consumer CSR discourse can overcome this limitation. Although this study considers the six most popular European destinations, cultural differences and reviewers' profiles may affect the results. Future steps in this line of research should take these elements into consideration to better understand how they impact consumers' CSR awareness. Hotels' rating, image (chain vs. independent), and branding should also be considered. Future research could also investigate the CSR discourse in peer-to-peer environments (e.g. Airbnb) to determine whether consumers who choose that type of accommodation integrate CSR elements in more detail in their reviews. Lastly, it would be interesting to study customers' willingness to book a room depending on hotels' CSR commitment through an experimental design (Matute-Vallejo et al., 2011). 


\section{References}

Aguinis, H. \& Glavas, A. (2012). What we know and don't know about corporate social responsibility: A review and research agenda. Journal of Management, 38(4), 932-968.

Aguinis, H. (2011). Organizational responsibility: Doing good and doing well. In S. Zedeck (Ed.), APA Handbook of Industrial and Organizational Psychology (Vol. 3): 855-879. Washington, DC: American Psychological Association

Ahluwalia, R. \& Shiv, B. (1997). Special session summary the effects of negative information in the political and marketing arenas: Exceptions to the negativity effect. ACR North American Advances.

Ayuso, S. (2006). Adoption of voluntary environmental tools for sustainable tourism: Analysing the experience of Spanish hotels. Corporate Social Responsibility and Environmental Management, 13(4), 207-220.

Auger, P., Burke, P., Devinney, T. M., \& Louviere, J. J. (2003). 'What will consumers pay for social product features?', Journal of Business Ethics 42 (February), 281-304.

Auger, P. \& Devinney, T. M. (2007). Do what consumers say matter? The misalignment of preferences with unconstrained ethical intentions. Journal of Business Ethics, 76(4), 361-383.

Babiak, K. \& Trendafilova, S. (2011). CSR and environmental responsibility: Motives and pressures to adopt green management practices. Corporate Social Responsibility and Environmental Management, 18(1), 11-24.

Berezina, K., Bilgihan, A., Cobanoglu, C., \& Okumus, F. (2016). Understanding satisfied and dissatisfied hotel customers: text mining of online hotel reviews. Journal of Hospitality Marketing \& Management, 25(1), 1-24.

Best Western. (2018). Retrieved September 26, 2018, from Error! Hyperlink reference not valid.

Bhattacharya, C. B. \& Sen, S. (2003). Consumer-company identification: A framework for understanding consumers' relationships with companies. Journal of Marketing, 67(2), 76-88.

Boes, K., Buhalis, D., \& Inversini, A. (2015). Conceptualising smart tourism destination dimensions. In Information and communication technologies in tourism 2015 (pp. 391-403). Springer, Cham.

Bohdanowicz, P. (2006). Environmental awareness and initiatives in the Swedish and Polish hotel industries - survey results. International Journal of Hospitality Management, 25(4), 662-682.

Bohdanowicz, P., Zientara, P., \& Novotna, E. (2011). International hotel chains and environmental protection: An analysis of Hilton's we care! programme (Europe, 2006-2008). Journal of Sustainable Tourism, 19(7), 797-816.

Boyd, R. L. \& Pennebaker, J. W. (2017). Language-based personality: A new approach to personality in a digital world. Current Opinion in Behavioral Sciences, 18, 63-68.

Brazyte, K., Weber, F., \& Schaffner, D. (2017). Sustainability management of hotels: How do customers respond in online reviews?. Journal of Quality Assurance in Hospitality \& Tourism, $18(3), 282-307$.

Bronner, F. \& De Hoog, R. (2011). Vacationers and eWOM: Who posts, and why, where, and what? Journal of Travel Research, 50(1), 15-26.

Buhalis, D. \& Law, R. (2008). Progress in information technology and tourism management: 20 years on and 10 years after the Internet-The state of eTourism research. Tourism Management, 29(4), 609-623.

Butler, J. (2008). The compelling "hard case" for "green" hotel development. Cornell Hospitality Quarterly, 49(3), 234-244.

Cantallops, A. S. \& Salvi, F. (2014). New consumer behavior: A review of research on eWOM and hotels. International Journal of Hospitality Management, 36, 41-51.

Carroll, A. B. \& Shabana, K. M. (2010). The business case for corporate social responsibility: A review of concepts, research and practice. International Journal of Management Reviews, 12(1), 85-105.

Chan, E. (2013). Gap analysis of green hotel marketing. International Journal of Contemporary Hospitality Management, 25(7), 1017-1048.

Chatterjee, P. (2001). Online reviews: Do consumers use them? ACR North American Advances. 
Choi, H., Jang, J., \& Kandampully, J. (2015). Application of the extended VBN theory to understand consumers' decisions about green hotels. International Journal of Hospitality Management, 51, 87-95.

Dameri, R. P. (2014). Comparing smart and digital city: Initiatives and strategies in Amsterdam and Genoa. Are they digital and/or smart? In Smart City (pp. 45-88). Springer, Cham.

De Grosbois, D. (2012). Corporate social responsibility reporting by the global hotel industry: Commitment, initiatives and performance. International Journal of Hospitality Management, 31(3), 896-905.

De Pelsmacker, P., Van Tilburg, S., \& Holthof, C. (2018). Digital marketing strategies, online reviews and hotel performance. International Journal of Hospitality Management, 72, 47-55.

Devinney, T. M., Auger, P., \& Eckhardt, G. M. (2010). The myth of the ethical consumer hardback with DVD. Cambridge University Press.

DiPietro, R., Cao, Y., \& Partlow, C. (2013). Green practices in upscale foodservice operations: Customer perceptions and purchase intentions. International Journal of Contemporary Hospitality Management, 25(5), 779-796.

Dodds, R. \& Kuehnel, J. (2010). CSR among Canadian mass tour operators: Good awareness but little action. International Journal of Contemporary Hospitality Management, 22(2), 221-244.

Dolnicar, S., Knezevic Cvelbar, L., \& Grün, B. (2017). Do pro-environmental appeals trigger proenvironmental behavior in hotel guests? Journal of Travel Research, 56(8), 988-997.

Dolnicar, S. \& Grün, B. (2009). Environmentally friendly behavior: Can heterogeneity among individuals and contexts/environments be harvested for improved sustainable management?. Environment and Behavior, 41(5), 693-714.

Du, S., Bhattacharya, C. B., \& Sen, S. (2007). Reaping relational rewards from corporate social responsibility: The role of competitive positioning. International Journal of Research in Marketing, 24(3), 224-241.

Erdogan, N. \& Baris, E. (2007). Environmental protection programs and conservation practices of hotels in Ankara, Turkey. Tourism Management, 28(2), 604-614.

Ettinger, A., Grabner-Kraeuter, S., \& Terlutter, R. (2018). Online CSR communication in the hotel industry: Evidence from small hotels. International Journal of Hospitality Management, 68, 94104.

Farrington, T., Curran, R., Gori, K., O'Gorman, K. D., \& Queenan, C. J. (2017). Corporate social responsibility: Reviewed, rated, revised. International Journal of Contemporary Hospitality Management, 29(1), 30-47.

Filieri, R. \& McLeay, F. (2014). E-WOM and accommodation: An analysis of the factors that influence travelers' adoption of information from online reviews. Journal of Travel Research, 53(1), 44-57.

Filieri, R., Alguezaui, S., \& McLeay, F. (2015). Why do travelers trust TripAdvisor? Antecedents of trust towards consumer-generated media and its influence on recommendation adoption and word of mouth. Tourism Management, 51, 174-185.

Frey, N. \& George, R. (2010). Responsible tourism management: The missing link between business owners' attitudes and behaviour in the Cape Town tourism industry. Tourism Management, 31(5), 621-628.

Gao, Y. L. \& Mattila, A. S. (2014). Improving consumer satisfaction in green hotels: The roles of perceived warmth, perceived competence, and CSR motive. International Journal of Hospitality Management, 42, 20-31.

GDCI, (2015). Mastercard global worldwide insights. Retrieved October 10, 2018, from https://newsroom.mastercard.com/wp-content/uploads/2015/06/MasterCard-GDCI-2015-FinalReport1.pdf

Giuliani, E., Santangelo, G. D., \& Wettstein, F. (2016). Human rights and international business research: A call for studying emerging market multinationals. Management and Organization Review, 12(3), 631-637.

Goldstein, K. A. \& Primlani, R. V. (2012). Current trends and opportunities in hotel sustainability. HVS Sustainability Services, 31. 
Guizzardi, A., Mariani, M., \& Prayag, G. (2017). Environmental impacts and certification: Evidence from the Milan World Expo 2015. International Journal of Contemporary Hospitality Management, 29(3), 1052-1071.

Han, H., Lee, J. S., Trang, H. L. T., \& Kim, W. (2018). Water conservation and waste reduction management for increasing guest loyalty and green hotel practices. International Journal of Hospitality Management, 75, 58-66.

Helen Chun, H. \& Giebelhausen, M. (2012). Reversing the green backlash in services: credible competitors help large companies go green. Journal of Service Management, 23(3), 400-415.

Hewett, K., Rand, W., Rust, R. T., \& Van Heerde, H. J. (2016). Brand buzz in the echoverse. Journal of Marketing, 80(3), 1-24.

Holcomb, J. L., Upchurch, R. S., \& Okumus, F. (2007). Corporate social responsibility: What are top hotel companies reporting?. International Journal of Contemporary Hospitality Management, 19(6), 461-475.

Humphreys, A. \& Wang, R. J.-H. (2017). Automated text analysis for consumer research. Journal of Consumer Research, 44(6), 1274-1306.Jones, P., Hillier, D., \& Comfort, D. (2016). Sustainability in the hospitality industry. International Journal of Contemporary Hospitality Management, 28(1), 36-67.

Kang, K. H., Lee, S., \& Huh, C. (2010). Impacts of positive and negative corporate social responsibility activities on company performance in the hospitality industry. Journal of Hospitality Management, 29(1), 72-82.

Kang, K. H., Stein, L., Heo, C. Y., \& Lee, S. (2012). Consumers' willingness to pay for green initiatives of the hotel industry. International Journal of Hospitality Management, 31(2), 564-572.

Kim, Y. (2017). Consumer responses to the food industry's proactive and passive environmental CSR, factoring in price as CSR tradeoff. Journal of Business Ethics, 140(2), 307-321.

Kim, E. E. K., Mattila, A. S., \& Baloglu, S. (2011). Effects of gender and expertise on consumers' motivation to read online hotel reviews. Cornell Hospitality Quarterly, 52(4), 399-406.

Kim, Y., Kim, M., \& Mattila, A. S. (2017). Corporate social responsibility and equity-holder risk in the hospitality industry. Cornell Hospitality Quarterly, 58(1), 81-93.

Kim, J., Kim, S., Lee, J. S., Kim, P. B., \& Cui, Y. (2019). Influence of choice architecture on the preference for a pro-environmental hotel. Journal of Travel Research, 0047287519841718.

Lee, H., Jai, T. M., \& Li, X. (2016). Guests' perceptions of green hotel practices and management responses on TripAdvisor. Journal of hospitality and tourism technology, 7(2), 182-199.

Lenzen, M., Sun, Y. Y., Faturay, F., Ting, Y. P., Geschke, A., \& Malik, A. (2018). The carbon footprint of global tourism. Nature Climate Change, 8(6), 522.

Leung, D., Law, R., Van Hoof, H., \& Buhalis, D. (2013). Social media in tourism and hospitality: A literature review. Journal of Travel \& Tourism Marketing, 30(1-2), 3-22.

Levy, S. E., Duan, W., \& Boo, S. (2013). An analysis of one-star online reviews and responses in the Washington, DC, lodging market. Cornell Hospitality Quarterly, 54(1), 49-63.

Li, C., Cui, G., \& Peng, L. (2017). The signaling effect of management response in engaging customers: A study of the hotel industry. Tourism Management, 62, 42-53.

Litvin, S. W., Goldsmith, R. E., \& Pan, B. (2008). Electronic word-of-mouth in hospitality and tourism management. Tourism Management, 29(3), 458-468.

Liu, M., Anthony Wong, I., Rongwei, C., \& Tseng, T. H. (2014). Do perceived CSR initiatives enhance customer preference and loyalty in casinos? International Journal of Contemporary Hospitality Management, 26(7), 1024-1045.

Liu, Y., Huang, K., Bao, J., \& Chen, K. (2019). Listen to the voices from home: An analysis of Chinese tourists' sentiments regarding Australian destinations. Tourism Management, 71, 337-347.

Liu, Z. \& Park, S. (2015). What makes a useful online review? Implication for travel product websites. Tourism Management, 47, 140-151.

Ludwig, S., De Ruyter, K., Friedman, M., Brüggen, E. C., Wetzels, M., \& Pfann, G. (2013). More than words: The influence of affective content and linguistic style matches in online reviews on conversion rates. Journal of Marketing, 77(1), 87-103. 
Ma, E., Cheng, M., \& Hsiao, A. (2018). Sentiment analysis - a review and agenda for future research in hospitality contexts. International Journal of Contemporary Hospitality Management.

MacKay, K. \& Vogt, C. (2012). Information technology in everyday and vacation contexts. Annals of Tourism Research, 39(3), 1380-1401.

Mankad, S., Han, H. S., Goh, J., \& Gavirneni, S. (2016). Understanding online hotel reviews through automated text analysis. Service Science, 8(2), 124-138.

Martínez, P., \& Del Bosque, I. R. (2013). CSR and customer loyalty: The roles of trust, customer identification with the company and satisfaction. International Journal of Hospitality Management, 35, 89-99.

Matute-Vallejo, J., Bravo, R., \& Pina, J. M. (2011). The influence of corporate social responsibility and price fairness on customer behaviour: evidence from the financial sector. Corporate Social Responsibility and Environmental Management, 18(6), 317-331.

Merli, R., Preziosi, M., Acampora, A., \& Ali, F. (2019). Why should hotels go green? Insights from guests experience in green hotels. International Journal of Hospitality Management, 81, 169-179.

Miao, L., \& Wei, W. (2013). Consumers' pro-environmental behavior and the underlying motivations: A comparison between household and hotel settings. International Journal of Hospitality Management, 32, 102-112.

Mkono, M. \& Tribe, J. (2017). Beyond reviewing: Uncovering the multiple roles of tourism social media users. Journal of Travel Research, 56(3), 287-298.

Moisescu, O. I. (2015). Communicating CSR in the online environment: Evidence from the Romanian tourism distribution sector. Tourism and Hospitality Management, 21(1), 79-94.

Morsing, M. \& Schultz, M. (2006). Corporate social responsibility communication: stakeholder information, response and involvement strategies. Business Ethics: A European Review, 15(4), 323-338.

Nicolau, J. L. (2008). Corporate social responsibility: Worth-creating activities. Annals of Tourism Research, 35(4), 990-1006.

Nielsen (2018). Was 2018 the year of the influential sustainable consumer? https://www.nielsen.com/us/en/insights/news/2018/was-2018-the-year-of-the-influentialsustainable-consumer.html

Nieto-García, M., Muñoz-Gallego, P. A., \& González-Benito, Ó. (2017). Tourists' willingness to pay for an accommodation: The effect of eWOM and internal reference price. International Journal of Hospitality Management, 62, 67-77.

Öberseder, M., Schlegelmilch, B. B., \& Gruber, V. (2011). "Why don't consumers care about CSR?”: A qualitative study exploring the role of CSR in consumption decisions. Journal of Business Ethics, 104(4), 449-460.

Park, D. H., Lee, J., \& Han, I. (2007). The effect of on-line consumer reviews on consumer purchasing intention: The moderating role of involvement. International journal of electronic commerce, 11(4), 125-148.

Park, S. Y. \& Allen, J. P. (2013). Responding to online reviews: Problem solving and engagement in hotels. Cornell Hospitality Quarterly, 54(1), 64-73.

Pencle, N. \& Mălăescu, I. (2016). What's in the words? Development and validation of a multidimensional dictionary for CSR and application using prospectuses. Journal of Emerging Technologies in Accounting, 13(2), 109-127.

Pennebaker, J. W., Booth, R. J., \& Francis, M. E. (2007). Linguistic inquiry and word count: LIWC [Computer software]. Austin, TX: liwc. net.

Peiró-Signes, A., Segarra-Oña, M. D. V., Verma, R., Mondéjar-Jiménez, J., \& Vargas-Vargas, M. (2014). The impact of environmental certification on hotel guest ratings. Cornell Hospitality Quarterly, 55(1), 40-51.

Planet 21 Accor Hotels. (2018). Retrieved June 3, 2018, from https://www.accorhotels.com/gb/sustainable-development/index.shtml

Pomering, A. \& Dolnicar, S. (2009). Assessing the prerequisite of successful CSR implementation: are consumers aware of CSR initiatives? Journal of Business Ethics, 85(2), 285-301.

Porter, M. E. \& Kramer, M. R. (2006). The link between competitive advantage and corporate social responsibility. Harvard Business Review, 84(12), 78-92. 
Racherla, P. \& Friske, W. (2012). Perceived 'usefulness' of online consumer reviews: An exploratory investigation across three services categories. Electronic Commerce Research and Applications, 11(6), 548-559.

Randle, M., Kemperman, A., \& Dolnicar, S. (2019). Making cause-related corporate social responsibility (CSR) count in holiday accommodation choice. Tourism Management, 75, 66-77.

Rodríguez, F. J. G. \& Cruz, Y. D. M. A. (2007). Relation between social-environmental responsibility and performance in hotel firms. International Journal of Hospitality Management, 26(4), 824-839.

Schrempf-Stirling, J. \& Wettstein, F. (2017). Beyond guilty verdicts: Human rights litigation and its impact on corporations' human rights policies. Journal of Business Ethics, 145(3), 545-562.

Schuckert, M., Liu, X., \& Law, R. (2015). Hospitality and tourism online reviews: Recent trends and future directions. Journal of Travel \& Tourism Marketing, 32(5), 608-621.

Sen, S. \& Bhattacharya, C. B. (2001). Does doing good always lead to doing better? Consumer reactions to corporate social responsibility. Journal of Marketing Research, 38(2), 225-243.

Sen, S., Bhattacharya, C. B., \& Korschun, D. (2006). The role of corporate social responsibility in strengthening multiple stakeholder relationships: A field experiment. Journal of the Academy of Marketing Science, 34(2), 158-166.

Sigala, M., Evangelos, C., \& Gretzel, U. (2012). Social media in travel, tourism and hospitality: Theory, practice and cases. Surrey, UK: Ashgate.

Sparks, B. A., Perkins, H. E., \& Buckley, R. (2013). Online travel reviews as persuasive communication: The effects of content type, source, and certification logos on consumer behavior. Tourism Management, 39, 1-9.

Su, L., Swanson, S. R., \& Chen, X. (2015). Social responsibility and reputation influences on the intentions of Chinese Huitang Village tourists: Mediating effects of satisfaction with lodging providers. International Journal of Contemporary Hospitality Management, 27(8), 1750-1771.

Sukhu, A., Choi, H., Bujisic, M., \& Bilgihan, A. (2019). Satisfaction and positive emotions: A comparison of the influence of hotel guests' beliefs and attitudes on their satisfaction and emotions. International Journal of Hospitality Management, 77, 51-63.

Torres, E. N., Singh, D., \& Robertson-Ring, A. (2015). Consumer reviews and the creation of booking transaction value: Lessons from the hotel industry. International Journal of Hospitality Management, 50, 77-83.

TripAdvisor. (2017). TripAdvisor reaches half a billion reviews and opinions and counting. Retrieved August 30, 2018, from http://ir.tripadvisor.com/news-releases/news-release-details/tripadvisorreaches-half-billion-reviews-and-opinions-and

Van Laer, T., Edson Escalas, J., Ludwig, S., \& Van Den Hende, E. A. (2018). What happens in Vegas stays on TripAdvisor? A theory and technique to understand narrativity in consumer reviews. Journal of Consumer Research.

Vermeulen, I. E. \& Seegers, D. (2009). Tried and tested: The impact of online hotel reviews on consumer consideration. Tourism Management, 30(1), 123-127.

Villarroel Ordenes, F., Grewal, D., Ludwig, S., Ruyter, K. D., Mahr, D., \& Wetzels, M. (2018). Cutting through content clutter: How speech and image acts drive consumer sharing of social media brand messages. Journal of Consumer Research, 45(5), 988-1012.

Wang, H., Tong, L., Takeuchi, R., \& George, G. (2016). Corporate social responsibility: An overview and new research directions. Academy of Management Journal, 59(2), 534-544.

Weber, M. (2008). The business case for corporate social responsibility: A company-level measurement approach for CSR. European Management Journal, 26(4), 247-261.

Welford, R., Chan, C., \& Man, M. (2008). Priorities for corporate social responsibility: A survey of businesses and their stakeholders. Corporate Social Responsibility and Environmental Management, 15(1), 52-62.

Wirtz, J. \& Chew, P. (2002). The effects of incentives, deal proneness, satisfaction and tie strength on word-of-mouth behaviour. International Journal of Service Industry Management, 13(2), 141-162.

World Conference on Human Rights. (1993). Vienna declaration and programme of action.

Xiang, Z., Du, Q., Ma, Y., \& Fan, W. (2017). A comparative analysis of major online review platforms: Implications for social media analytics in hospitality and tourism. Tourism Management, 58, 51-65. 
Xiang, Z., Schwartz, Z., Gerdes Jr, J. H., \& Uysal, M. (2015). What can big data and text analytics tell us about hotel guest experience and satisfaction? International Journal of Hospitality Management, 44, 120-130.

Xie, K. L., Zhang, Z., \& Zhang, Z. (2014). The business value of online consumer reviews and management response to hotel performance. International Journal of Hospitality Management, 43, $1-12$.

Xu, X. \& Li, Y. (2016). The antecedents of customer satisfaction and dissatisfaction toward various types of hotels: A text mining approach. International Journal of Hospitality Management, 55, 57 69.

$\mathrm{Xu}$, Y. (2014). Understanding CSR from the perspective of Chinese diners: The case of McDonald's. International Journal of Contemporary Hospitality Management, 26(6), 1002-1020.

Ye, Q., Law, R., \& Gu, B. (2009). The impact of online user reviews on hotel room sales. International Journal of Hospitality Management, 28(1), 180-182.

Yu, Y., Li, X., \& Jai, T. M. (2017). The impact of green experience on customer satisfaction: Evidence from TripAdvisor. International Journal of Contemporary Hospitality Management, 29(5), 1340-1361.

Zeithaml, V. A., Bitner, M. J., \& Gremler, D. D. (2006). Services marketing: Integrating consumer focus across the firm.

Zhang, H., Gordon, S., Buhalis, D., \& Ding, X. (2018). Experience value cocreation on destination online platforms. Journal of Travel Research, 57(8), 1093-1107.

Zhao, Y., Xu, X., \& Wang, M. (2019). Predicting overall customer satisfaction: Big data evidence from hotel online textual reviews. International Journal of Hospitality Management, 76, 111-121.

Zhou, L., Ye, S., Pearce, P. L., \& Wu, M. Y. (2014). Refreshing hotel satisfaction studies by reconfiguring customer review data. International Journal of Hospitality Management, 38, $1-10$. 